\title{
A Biocompatible Colorimetric Triphenylamine- Dicyanovinyl Conjugated Fluorescent Probe for Selective and Sensitive Detection of Cyanide Ion in Aqueous Media and Living Cells
}

\author{
Zi-Hua Zheng ${ }^{1,2}{ }^{,}$Zhi-Ke Li ${ }^{3}$, Lin-Jiang Song ${ }^{3}$, Qi-Wei Wang ${ }^{1}$, Qing-Fei Huang ${ }^{1, *}$ \\ and Li Yang ${ }^{3, *}$ \\ 1 Chengdu Institute of Organic Chemistry, Chinese Academy of Sciences, Chengdu 610041, China; \\ Zhengzihua14@mails.ucas.ac.cn (Z.-H.Z.); wqw@cioc.ac.cn (Q.-W.W.) \\ 2 University of Chinese Academy of Sciences, Beijing 100049, China \\ 3 Cancer Center, West China Hospital, Sichuan University and Collaborative Innovation Center, \\ Chengdu 610041, China; 18280127765@163.com (Z.-K.L.); linjsong_scu@163.com (L.-J.S.) \\ * Correspondence: qfhuang@cioc.ac.cn (Q.-F.H.); yangli@scu.edu.cn (L.Y.); Tel.: +86-28-8550-2157 (L.Y.)
}

Academic Editors: Jong Seung Kim and Min Hee Lee

Received: 12 December 2016; Accepted: 4 February 2017; Published: 19 February 2017

\begin{abstract}
A colorimetric and turn-on fluorescent probe 1 bearing triphenylamine-thiophene and dicyanovinyl groups has been synthesized and used to detect cyanide anion via a nucleophilic addition reaction. Probe 1 exhibited prominent selectivity and sensitivity towards $\mathrm{CN}^{-}$in aqueous media, even in the presence of other anions such as $\mathrm{S}^{2-}, \mathrm{HS}^{-}, \mathrm{SO}_{3}{ }^{2-}, \mathrm{S}_{2} \mathrm{O}_{3}{ }^{2-}, \mathrm{S}_{2} \mathrm{O}_{8}{ }^{2-}, \mathrm{I}^{-}, \mathrm{Br}^{-}, \mathrm{Cl}^{-}$, $\mathrm{F}^{-}, \mathrm{NO}_{2}{ }^{-}, \mathrm{N}_{3}{ }^{-}, \mathrm{SO}_{4}{ }^{2-}, \mathrm{SCN}^{-}, \mathrm{HCO}_{3}{ }^{-}, \mathrm{CO}_{3}{ }^{2-}$ and $\mathrm{AcO}^{-}$. Moreover, a low detection limit (LOD, $51 \mathrm{nM}$ ) was observed. In addition, good cell membrane permeability and low cytotoxicity to HeLa cells were also observed, suggesting its promising potential in bio-imaging.
\end{abstract}

Keywords: biocompatible; cell imaging; colorimetric assay; dicyanovinyl; cyanide anion

\section{Introduction}

Anions play an important role in a wide range of chemical and biological processes. Given this, anion recognition has been well studied in recent years [1]. Among various anions, cyanide anion $\left(\mathrm{CN}^{-}\right)$is a well-known anion that is toxic to living organisms [2]. As advocated by the World Health Organization (WHO), the maximum concentration of cyanide anion in drinking water should be $1.9 \mu \mathrm{M}$ [3]. However, $\mathrm{CN}^{-}$is widely released from industry waste, certain natural plants, cigarette smoke, etc. [4], and can thus be a serious threat to people's health and the environment. Hence, developing effective quantitative determination methods for $\mathrm{CN}^{-}$is urgent and essential.

In order to quickly, easily and accurately detect cyanide anion, various analysis methods were developed, including titrimetric [5], electrochemical decices [6-8], voltammetric [9], fluorometric [10-17] and so on. Compared with other methods, fluorometric and colorimetric responses based on chemical reactions have attracted much attention due to their simple operation, high selectivity, high sensitivity and low cost [18-22]. The sensing mechanisms of fluorometric and colorimetric chemosenors for detecting $\mathrm{CN}^{-}$have been reported over the past few years, including hydrogen bonding reactions [23-27], forming cyanide anion complexes [28,29], electron transfer reactions [30-32] and nucleophilic addition reactions [33-40]. Among them, the nucleophilic addition reactions generally have high selectivity for detecting $\mathrm{CN}^{-}$.

Triphenylamine-based thiophene dicyanovinyl compounds, which contain an electron-donating triphenylamine moiety and a strong electron-withdrawing dicyanovinyl group, were reported as 
red-emitting fluorophores with large Stokes shifts [41]. In recent years, some fluorescent probes with dicyanovinyl moieties for detecting cyanide anions have been reported [42-47]. Consequently, we hypothesized that triphenylamine-based thiophene dicyanovinyl compounds could be applied to selectively detect cyanide anion.

With this hypothesis in mind, probe 1 was synthesized and exhibited prominent selectivity and sensitivity towards cyanide anion with significant turn-on fluorescent response in PBS/DMSO $(4 / 6, v / v, \mathrm{pH}=7.4)$ solution (Scheme 1$)$. Herein, we report a dual colorimetric and fluoresecent probe to selectively and sensitively detect cyanide anion in aqueous media. Moreover, low cytotoxicity and good cell membrane permeability in HeLa cells were also observed, suggesting its promising potential in bio-imaging.

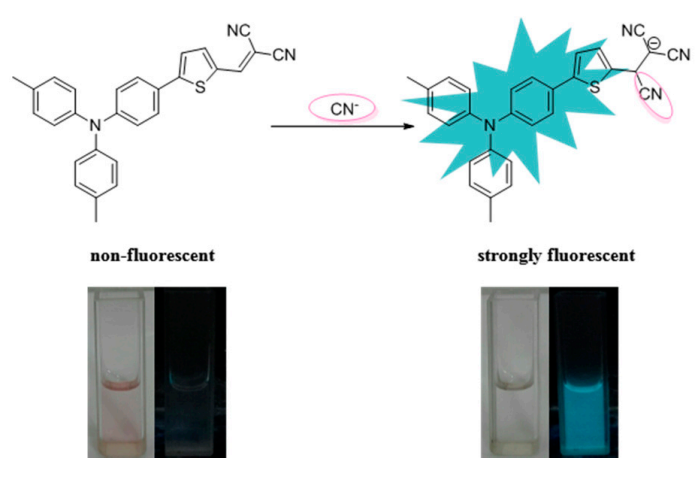

Scheme 1. The sensing mechanism of probe 1.

\section{Results and Discussion}

\subsection{Synthesis of Probe 1}

As shown in Scheme 2, probe 1 was synthesized via a 3-step synthesis route according to a literature method [41]. The structure of probe 1 was fully characterized by NMR and ESI-MS spectroscopy. Detailed synthetic process and structure characterization are given in the Experimental section and in the Electronic Supplementary Information (ESI).

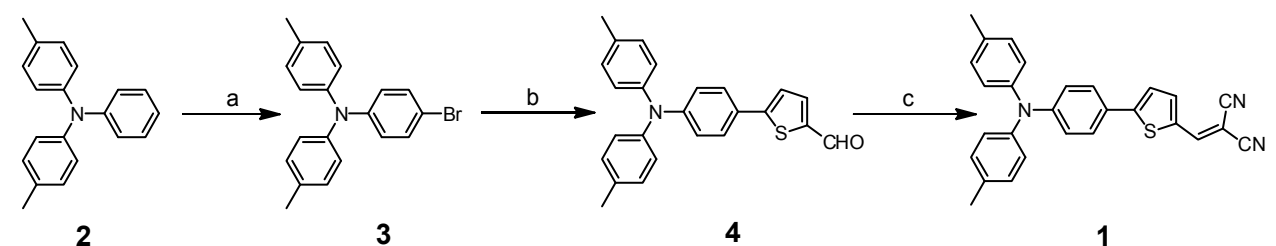

Scheme 2. The synthesis of probe 1; Reagents and Conditions: (a) NBS, DMF, r.t., 99\% yield; (b) (5-formylthiophen-2-yl) boronic acid, $\mathrm{Pd}\left(\mathrm{PPh}_{3}\right)_{4}$, dioxane, reflux, $3.5 \mathrm{~h}, 67 \%$ yield; (c) malononitrile, piperidine, reflux, $3 \mathrm{~h}, 70 \%$ yield.

\subsection{Selectivity over Other Anions}

After the identification of the optimal fluorescence measurement conditions, a series of relevant and interfering anions were investigated to study the selectivity. Before the addition of various anions, the light-pink probe solution is non-fluorescent upon excited at $370 \mathrm{~nm}$. The addition of 10 equivalents of 16 representative anions $\left(\mathrm{S}^{2-}, \mathrm{HS}^{-}, \mathrm{SO}_{3}{ }^{2-}, \mathrm{S}_{2} \mathrm{O}_{3}{ }^{2-}, \mathrm{S}_{2} \mathrm{O}_{8}{ }^{2-}, \mathrm{I}^{-}, \mathrm{Br}^{-}, \mathrm{Cl}^{-}, \mathrm{F}^{-}, \mathrm{NO}_{2}{ }^{-}, \mathrm{N}_{3}{ }^{-}, \mathrm{SO}_{4}{ }^{2-}\right.$, $\mathrm{SCN}^{-}, \mathrm{HCO}_{3}{ }^{-}, \mathrm{CO}_{3}{ }^{2-}$ and $\mathrm{AcO}^{-}$) did not cause significant fluorescence changes (Figure 1a), whereas the color of the probe 1 solution faded in the presence of $\mathrm{CN}^{-}$(10 equiv.) and the fluorescence intensity enhancement at $480 \mathrm{~nm}$ was remarkable. Based on the good selectivity of probe $\mathbf{1}$ toward $\mathrm{CN}^{-}$, competition experiments were further explored. As shown in Figure 1b, the fluorescence intensity of 
probe $+\mathrm{CN}^{-}$remained at a high level by the addition of other interfering anions (10 equiv.), suggesting that the response of probe $\mathbf{1}$ toward $\mathrm{CN}^{-}$has good anti-interference ability.
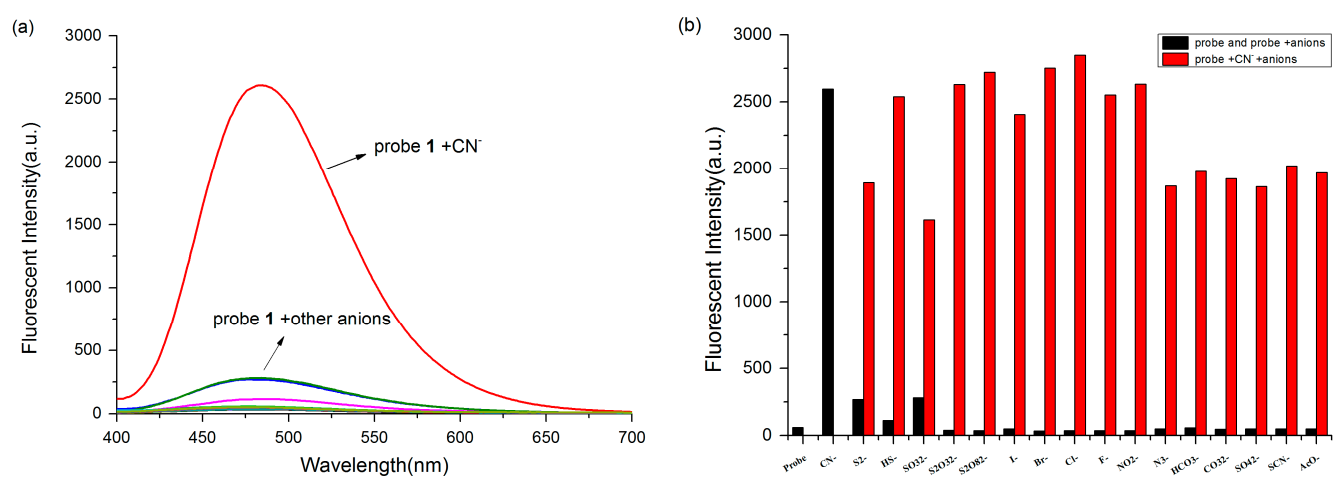

Figure 1. (a) Fluorescent responses of probe $\mathbf{1}(5 \mu \mathrm{M})$ towards various anions $(50 \mu \mathrm{M})$ in PBS/DMSO $(4 / 6, \mathrm{pH}=7.4)$ solution. $\lambda_{\mathrm{ex}}=370 \mathrm{~nm}$, Slits: $2.5 \mathrm{~nm} / 5 \mathrm{~nm}$; (b) Competing responses of probe $\mathbf{1}(5 \mu \mathrm{M})$ at $480 \mathrm{~nm}$ towards various analytes $(50 \mu \mathrm{M})$ in $\mathrm{PBS} / \mathrm{DMSO}(4 / 6, \mathrm{pH}=7.4)$ solution. Black bar, probe and probe + anions; red bar, probe $+\mathrm{CN}^{-}+$anions. $\lambda_{\mathrm{ex}}=370 \mathrm{~nm}$, Slits: $2.5 \mathrm{~nm} / 5 \mathrm{~nm}$.

\subsection{Colorimetric and Fluorescent Detection}

The UV-vis spectra changes of probe $1(5 \mu \mathrm{M})$ upon addition of $\mathrm{CN}^{-}(50 \mu \mathrm{M})$ in PBS/DMSO $(4 / 6, \mathrm{pH}=7.4)$ solution can be clearly observed (Figure S1) and the absorption at $505 \mathrm{~nm}$ decreased. The free probe 1 exhibits absorption at $505 \mathrm{~nm}$ with a pink color because of ICT process in the large $\pi$-conjugation. Subsequently, a colorimetric assay was performed. As shown in Figure 2a, among tested analytes, only cyanide anion resulted in an obvious color change from light pink to colourless. Moreover, a bright blue light was achieved in the solution of probe 1 with $\mathrm{CN}^{-}$under the irradiation of a UV-lamp at $365 \mathrm{~nm}$, which is visible by the naked eye (Figure $2 \mathrm{~b}$ ).

(a)
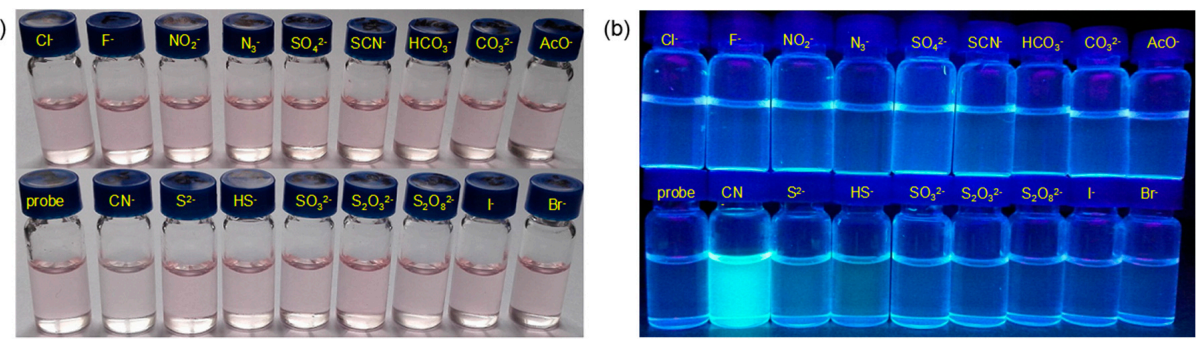

Figure 2. Fluorescence images of probe $1(5 \mu \mathrm{M})$ upon addition of various anions $(50 \mu \mathrm{M})$ in PBS/DMSO $(4 / 6, \mathrm{pH}=7.4)$ solution under visible light (a); and $365 \mathrm{~nm} \mathrm{UV} \mathrm{lamp} \mathrm{(b).}$

\subsection{Spectral Titration of Probe 1}

The fluorescence titration experiment was performed by adding different concentrations of cyanide anion ranging from 0 to $75 \mu \mathrm{M}$ to a $5 \mu \mathrm{M}$ solution of probe 1 (Figure S3). Saturation was observed when the concentration of cyanide anion was raised to $62.5 \mu \mathrm{M}$. As shown in Figure 3a, a concentration-dependent fluorescence enhancement was observed when $\mathrm{CN}^{-}$from 0 to $25 \mu \mathrm{M}$ was added at $480 \mathrm{~nm}$. A good linear relationship between the fluorescence intensity and the concentration of $\mathrm{CN}^{-}$could be obtained in the range of 0 to $25 \mu \mathrm{M}\left(\mathrm{R}^{2}=0.99698\right)$.

To calculate the limit of detection (LOD), the standard deviation of the blank measurements was determined by measuring the fluorescent intensity of probe 110 times [48-50]. Based on the equation $(\mathrm{LOD}=3 \sigma / \mathrm{m})$ and the fluorescence titration, the LOD was calculated to be $51 \mathrm{nM}$, which is much lower than the maximum level of cyanide anion $(1.9 \mu \mathrm{M})$ in drinking water permitted by the WHO, suggesting its promising potential for the detection of low levels of cyanide anion in water samples. 

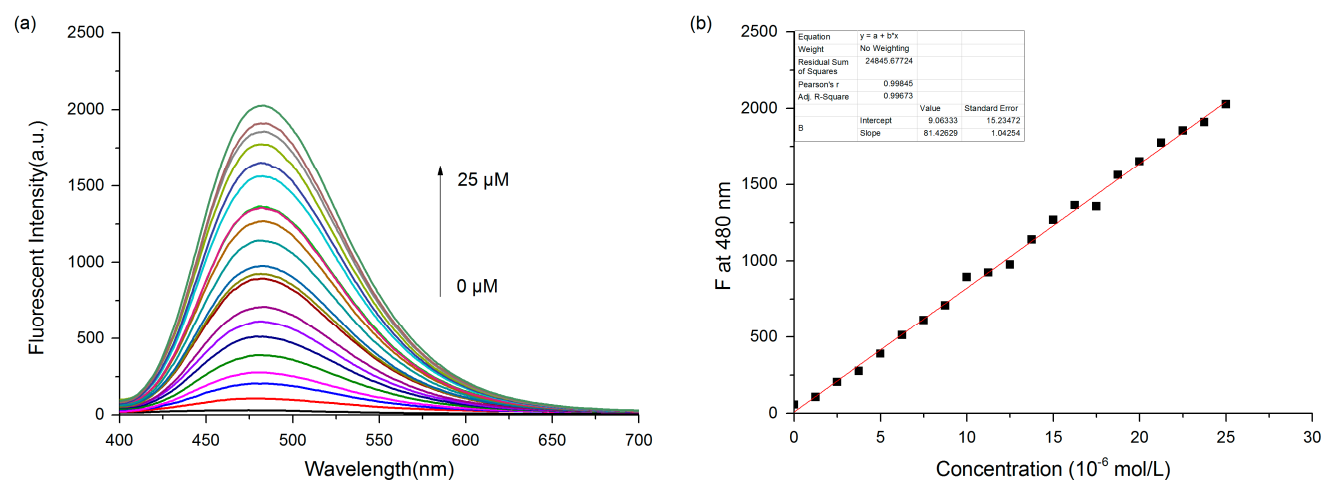

Figure 3. (a) Fluorescence spectra of probe $1(5 \mu \mathrm{M})$ in the presence of various concentration of $\mathrm{CN}^{-}$ $(0-25 \mu \mathrm{M})$ in PBS/DMSO (4/6, pH = 7.4) solution; (b) Linear relation between the fluorescent intensity at $480 \mathrm{~nm}$ and the concentration of $\mathrm{CN}^{-}$in the range of $0-25 \mu \mathrm{M}$. $\lambda_{\mathrm{ex}}=370 \mathrm{~nm}$, Slits: $2.5 \mathrm{~nm} / 5 \mathrm{~nm}$.

\subsection{The Sensing Mechanism}

As proposed in the literature [51], the sensing mechanism of probe $\mathbf{1}$ based on a nucleophilic addition reaction has been confirmed by ${ }^{1} \mathrm{H}-\mathrm{NMR}$ spectroscopy (Figure 4 ). Thus, to a $20 \mathrm{mM}$ solution of probe 1 in $\mathrm{CDCl}_{3}$ cyanide anion (0.5 equiv.) was added at room temperature and a new proton signal appeared at $4.5 \mathrm{ppm}\left(\mathrm{H}^{2 \mathrm{a}}\right)$. When the amount of $\mathrm{CN}^{-}$was raised to 1.0 equiv., some significant proton signal changes were observed. For example, the vinyl proton signal $\left(\mathrm{H}^{1 \mathrm{a}}, 7.73 \mathrm{ppm}\right)$ disappeared gradually and a new proton signal at $4.5 \mathrm{ppm}\left(\mathrm{H}^{2 \mathrm{a}}\right)$ was observed. The two proton signals on the thiophene ring $\left(\mathrm{H}^{1 \mathrm{~b}}, 7.66 \mathrm{ppm} ; \mathrm{H}^{1 \mathrm{c}}, 7.30 \mathrm{ppm}\right)$ disappeared and were observed around $7.00 \mathrm{ppm}$. In addition, the two proton signals $\left(\mathrm{H}^{1 \mathrm{~d}}\right)$ adjacent to the thiophene ring shifted from $7.49 \mathrm{ppm}$ to $7.36 \mathrm{ppm}$. These important proton signal changes conformed with the reference. While 1.5 equiv. $\mathrm{CN}^{-}$ was added, the reaction accomplished completely. In addition, the $[\mathbf{1}-\mathbf{C N}]^{-}$adduct was characterized by mass spectrometry analysis, and the peak at $m / z 457.1471$ (calc. 457.1492) corresponding to $\left[\mathbf{1}-\mathrm{CN}^{-}\right.$was clearly observed (Figure S10).

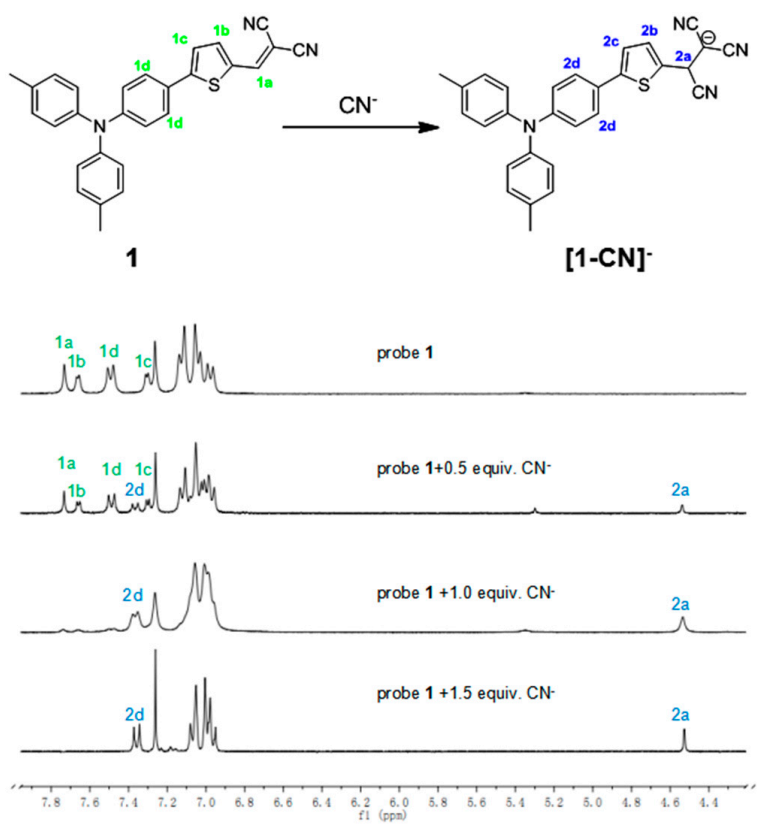

Figure 4. ${ }^{1} \mathrm{H}-\mathrm{NMR}$ spectral changes of probe $\mathbf{1}(20 \mathrm{mM})$ upon addition of $\mathrm{CN}^{-}$(as tetrabutylammonium salts) in $\mathrm{CDCl}_{3}$. 


\subsection{Cellular Imaging}

To explore its potential in bio-imaging, the cytotoxicity of probe 1 was investigated by a standard MTT assay. As shown in Figure 5, HeLa cell viability was slightly reduced when the probe concentration was raised up to $40 \mu \mathrm{M}$, indicating acceptable cytotoxicity of probe 1 .

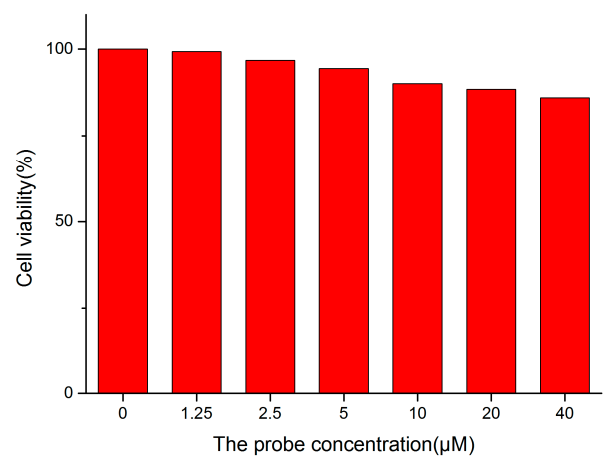

Figure 5. HeLa cell viability values (\%) estimated by MTT assay at different concentrations of probe 1 for $24 \mathrm{~h}$.

Probe 1 was next applied to detect cyanide anion in living HeLa cells. As shown in Figure 6, HeLa cells were incubated with probe $\mathbf{1}(10 \mu \mathrm{M})$ for $1 \mathrm{~h}$ and then with different concentrations of $\mathrm{CN}^{-}$ (A, E: $0 \mu \mathrm{M}$; B, F: $10 \mu \mathrm{M}$; C, G: $80 \mu \mathrm{M}$; D, H: $160 \mu \mathrm{M}$ ) for $15 \mathrm{~min}$. Under the fluorescent microscope, remarkable intracellular blue fluorescence was observed (Figure 6G-H). Moreover, the fluorescence intensity showed a concentration-dependent manner. As shown in Figure 7, HeLa cells were incubated with different concentrations of probe $(0 \mu \mathrm{M} ; 2.5 \mu \mathrm{M} ; 5.0 \mu \mathrm{M} ; 10 \mu \mathrm{M})$ for $1 \mathrm{~h}$ and then with $\mathrm{CN}^{-}(80 \mu \mathrm{M})$ for $15 \mathrm{~min}$. The fluorescence intensity also showed a concentration-dependent manner. In summary, probe 1 showed the potential to detect $\mathrm{CN}^{-}$in vitro cellular systems in a concentration-dependent manner for both probe and $\mathrm{CN}^{-}$.
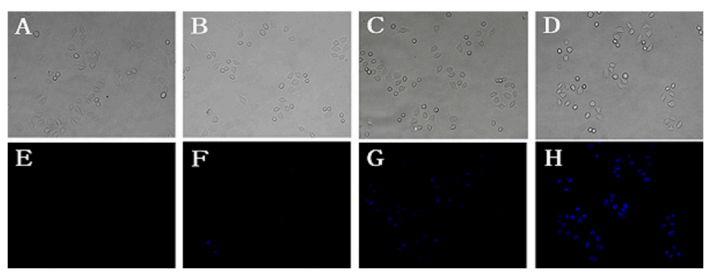

Figure 6. Images of living HeLa cells: HeLa cells incubated with probe $\mathbf{1}(10 \mu \mathrm{M})$ for $1 \mathrm{~h}$ and then with different concentration of $\mathrm{CN}^{-}((\mathbf{A}, \mathbf{E}) 0 \mu \mathrm{M}$; (B,F) $10 \mu \mathrm{M}$; (C,G) $80 \mu \mathrm{M} ;(\mathbf{D}, \mathbf{H}) 160 \mu \mathrm{M})$ for $15 \mathrm{~min}$. (A-D) is Bright field; $(\mathrm{E}-\mathrm{H})$ is under fluorescence $\left(\lambda_{\mathrm{ex}}=385 \mathrm{~nm}, \lambda_{\mathrm{em}}=405-440 \mathrm{~nm}\right)$ blue channel (425 nm-520 nm), scale bar: $20 \mu \mathrm{m}$.

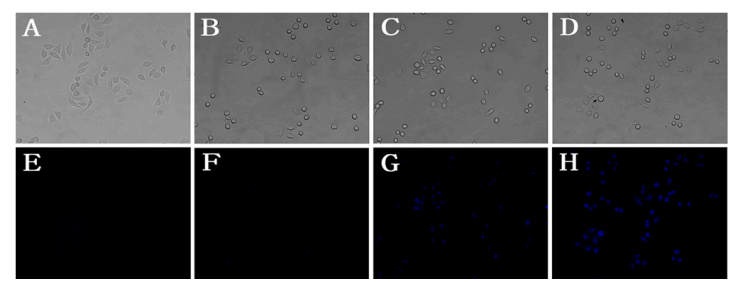

Figure 7. Images of living HeLa cells: HeLa cells incubated with different concentration of probe 1 $((\mathbf{A}, \mathbf{E}) 0 \mu \mathrm{M}$; (B,F) $2.5 \mu \mathrm{M}$; (C,G) $5 \mu \mathrm{M} ;(\mathbf{D}, \mathbf{H}) 10 \mu \mathrm{M})$ for $1 \mathrm{~h}$ and then all cells were incubated with $80 \mu \mathrm{M} \mathrm{CN}^{-}$for $15 \mathrm{~min}$. (A-D) is Bright field; $(\mathbf{E}-\mathbf{H})$ is under fluorescence $\left(\lambda_{\mathrm{ex}}=385 \mathrm{~nm}\right.$, $\lambda_{\mathrm{em}}=405-440 \mathrm{~nm}$ ), scale bar: $20 \mu \mathrm{m}$. 


\section{Experimental Section}

\subsection{Materials and Instruments}

All reagents were of analytical grade and used without further purification. The absorption and fluorescence spectra were measured on a UV-2450 (Shimadzu, Kyoto, Japan) instrument and a F-7000 (Hitachi, Tokyo, Japan) fluorescence spectrometer. ${ }^{1} \mathrm{H}-\mathrm{NMR}$ (300 MHz) and ${ }^{13} \mathrm{C}-\mathrm{NMR}(75 \mathrm{MHz})$ spectra were obtained on a Bruker-300 MHz spectrometer (Bruker, Fällanden, Switzerland) using tetramethylsilane (TMS) as an internal standard. The following abbreviations were used to denote the signal multiplicities: $\mathrm{s}$ for singlet, $\mathrm{d}$ for doublet, $\mathrm{t}$ for triplet, $\mathrm{q}$ for quartet, $\mathrm{m}$ for multiplet, br for broad. High-resolution mass spectra were obtained on a micrOTOF-Q mass spectrometer (Bruker, Bremen, Germany). Fluorescence cell imaging was performed with a fluorescence microscope (Olympus, Tokyo, Japan) with a $40 \times$ objective lens.

\subsection{Synthesis of Probe 1}

\subsubsection{Synthesis of 4-bromo-N,N-di-p-tolylaniline (3)}

4-Methyl-N-phenyl-N-(p-tolyl)aniline $(1.00 \mathrm{~g}, 3.66 \mathrm{mmol})$ and NBS (0.68 g, $3.84 \mathrm{mmol})$ were dissolved in $\mathrm{CHCl}_{3}(20 \mathrm{~mL})$. The mixture was stirred for $1.5 \mathrm{~h}$ at room temperature. The mixture was poured into water $(50 \mathrm{~mL})$ and then extracted with dichloromethane. The organic layer was washed with plenty of brine and dried over anhydrous sodium sulfate. The solvent was evaporated by a rotary evaporator. A white solid (1.28 g) was obtained. Yield: 99\%. ${ }^{1} \mathrm{H}-\mathrm{NMR}\left(\mathrm{CDCl}_{3}\right): \delta 7.26(\mathrm{~d}, J=9.0 \mathrm{~Hz}$, $1 \mathrm{H}), 7.06(\mathrm{~d}, J=8.2 \mathrm{~Hz}, 2 \mathrm{H}), 6.96(\mathrm{~d}, J=9.0 \mathrm{~Hz}, 2 \mathrm{H}), 6.87(\mathrm{~d}, J=6.0 \mathrm{~Hz}, 1 \mathrm{H}), 2.30(\mathrm{~s}, 3 \mathrm{H})$.

\subsubsection{Synthesis of 5-(4-(di-p-tolylamino)phenyl)thiophene-2-carbaldehyde (4)}

Dioxane $(50 \mathrm{~mL})$ was placed in a 3-necked round bottom flask and was purged with nitrogen for $30 \mathrm{~min}$. Under a nitrogen atmosphere, compound 3 (1.00 g, $2.84 \mathrm{mmol})$, (5-formylthiophen-2-yl)boronic acid $(1.35 \mathrm{~g}, 3.40 \mathrm{mmol}), \mathrm{K}_{2} \mathrm{CO}_{3}(2.00 \mathrm{~g}, 5.68 \mathrm{mmol})$ and $\mathrm{Pd}\left(\mathrm{PPh}_{3}\right)_{4}(164 \mathrm{mg}, 0.14 \mathrm{mmol})$ were added. The mixture was violently refluxed for $3.5 \mathrm{~h}$. After cooling to room temperature, the solvent was evaporated by a rotary evaporator. The residue was purified by column chromatography (silica gel, ethyl acetate/petroleum ether $=1: 20)$ to give the compound 4 . The product was obtained as a yellow solid (0.73 g). Yield: 67\%. ${ }^{1} \mathrm{H}-\mathrm{NMR}\left(\mathrm{DMSO}-d_{6}\right): \delta 9.84(\mathrm{~s}, 1 \mathrm{H}), 7.93(\mathrm{~d}, J=4.0 \mathrm{~Hz}, 1 \mathrm{H}), 7.62(\mathrm{~d}, J=7.6 \mathrm{~Hz}$, $2 \mathrm{H}), 7.56(\mathrm{~d}, J=4.0 \mathrm{~Hz}, 1 \mathrm{H}), 7.15(\mathrm{~d}, J=8.2 \mathrm{~Hz}, 4 \mathrm{H}), 6.98(\mathrm{~d}, J=8.3 \mathrm{~Hz}, 4 \mathrm{H}), 6.86(\mathrm{~d}, J=8.8 \mathrm{~Hz}, 2 \mathrm{H})$, $2.27(\mathrm{~s}, 6 \mathrm{H}) ;{ }^{13} \mathrm{C}-\mathrm{NMR}$ (DMSO- $\left.d_{6}\right): \delta 183.6,153.2,148.9,143.9,140.6,139.5,133.5,130.3,127.3,125.3$, $124.5,123.6,120.3,20.5$.

\subsubsection{Synthesis of 2-((5-(4-(di-p-tolylamino)phenyl)thiophen-2-yl)methylene)malononitrile (1)}

To a solution of compound $4(50 \mathrm{mg}, 0.13 \mathrm{mmol})$ and malononitrile $(13 \mathrm{mg}, 0.19 \mathrm{mmol})$ dissolved in toluene $(3 \mathrm{~mL})$, and a drop of piperidine was added under a nitrogen atmosphere. The mixture was refluxed for $3 \mathrm{~h}$. After cooling to room temperature, the solvent was evaporated by a rotary evaporator. The residue was purified by column chromatography (silica gel, ethyl acetate/petroleum ether $=1: 10$ ) to give the title compound 1 as a red solid $(47 \mathrm{mg})$. Yield: $70 \% .{ }^{1} \mathrm{H}-\mathrm{NMR}\left(\mathrm{CDCl}_{3}\right): \delta 7.73(\mathrm{~s}, 1 \mathrm{H}), 7.66$ $(\mathrm{d}, J=4.0 \mathrm{~Hz}, 1 \mathrm{H}), 7.49(\mathrm{~d}, J=8.8 \mathrm{~Hz}, 2 \mathrm{H}), 7.30(\mathrm{~d}, J=4.1 \mathrm{~Hz}, 1 \mathrm{H}), 7.13(\mathrm{~d}, J=8.2 \mathrm{~Hz}, 4 \mathrm{H}), 7.04(\mathrm{~d}$, $J=8.3 \mathrm{~Hz}, 4 \mathrm{H}), 6.98(\mathrm{~d}, J=8.7 \mathrm{~Hz}, 2 \mathrm{H}), 2.35(\mathrm{~s}, 6 \mathrm{H}) ;{ }^{13} \mathrm{C}-\mathrm{NMR}\left(\mathrm{CDCl}_{3}\right): \delta 157.5,150.3,150.2,143.9$, $140.5,134.2,132.8,130.2,127.5,125.6,123.8,122.9,120.4,114.6,113.7,74.5,20.9$; HRMS (ESI): $m / z$, $[\mathrm{M}+\mathrm{H}]^{+}$calcd. for $\mathrm{C}_{28} \mathrm{H}_{22} \mathrm{~N}_{3} \mathrm{~S}^{+}, 432.1529$; found, 432.1516 .

\subsection{General Fluorescence Spectra Measurements}

Figure S4 shows that the fluorescence intensity of probe $1(5 \mu \mathrm{M})$ was slightly affected within a range of $\mathrm{pH}(7.0-9.0)$ in the absence and presence of $\mathrm{CN}^{-}(50 \mu \mathrm{M})$ in PBS/DMSO (4/6) solution. The fluorescence responses of probe 1 were investigated in $\operatorname{PBS} / \mathrm{DMSO}(4: 6, v / v, \mathrm{pH}=7.4)$ solution. 
The response time of the probe 1 towards $\mathrm{CN}^{-}$was $80 \mathrm{~min}$ (Figure S2). To ensure the reaction accomplish completely, fluorescence measurements were delayed for $1.5 \mathrm{~h}$ after anion addition.

Probe 1 was dissolved in DMSO to afford a concentration of $5 \mathrm{mM}$ stock solution and then diluted to $5 \mu \mathrm{M}$ with $\mathrm{PBS} / \mathrm{DMSO}=4 / 6(v / v, \mathrm{pH}=7.4)$. Cyanide anion $(10 \mathrm{mM})$ was offered by tetrabutylammonium cyanide. Moreover, miscellaneous interference anions (as their $\mathrm{Na}^{+}$or $\mathrm{K}^{+}$ salt, $10 \mathrm{mM}$ ) including $\mathrm{S}^{2-}, \mathrm{HS}^{-}, \mathrm{SO}_{3}{ }^{2-}, \mathrm{S}_{2} \mathrm{O}_{3}{ }^{2-}, \mathrm{S}_{2} \mathrm{O}_{8}{ }^{2-}, \mathrm{I}^{-}, \mathrm{Br}^{-}, \mathrm{Cl}^{-}, \mathrm{F}^{-}, \mathrm{NO}_{2}{ }^{-}, \mathrm{N}_{3}{ }^{-}, \mathrm{SO}_{4}{ }^{2-}$, $\mathrm{SCN}^{-}, \mathrm{HCO}_{3}{ }^{-}, \mathrm{CO}_{3}{ }^{2-}$ and $\mathrm{AcO}^{-}$in deionized water were used for the sensing experiments. The fluorescence spectrum changes caused by $\mathrm{CN}^{-}(50 \mu \mathrm{M})$ and miscellaneous interference anions $(50 \mu \mathrm{M})$ were recorded at room temperature using a fluorescence spectrometer $\left(\lambda_{\mathrm{ex}}=370 \mathrm{~nm}, \lambda_{\mathrm{em}}=480 \mathrm{~nm}\right.$, slits: $2.5 \mathrm{~nm} / 5 \mathrm{~nm})$.

\subsection{Cell Culture and Confocal Fluorescence Imaging}

HeLa cells were obtained from the State Key Laboratory of Biotherapy of Sichuan University. Cells were seeded to a 12 -well plates, and were routinely maintained at $37{ }^{\circ} \mathrm{C}$ in a humidified $5 \% \mathrm{CO}_{2}$ atmosphere using DMEM Growth medium with $10 \%$ fetal bovine serum for $24 \mathrm{~h}$ before use.

HeLa cells (Figure 6) were incubated with probe $\mathbf{1}(10 \mu \mathrm{M})$ for $1 \mathrm{~h}$, and then washed with PBS five times. All cells were incubated with PBS for $15 \mathrm{~min}$; finally with different concentrations of $\mathrm{CN}^{-}$ were added for $1 \mathrm{~h}$ at $37^{\circ} \mathrm{C}$ : A, E with PBS; B, F with $10 \mu \mathrm{MCN}^{-}$; C, G with $80 \mu \mathrm{M} \mathrm{CN}^{-}$; D, H with $160 \mu \mathrm{M} \mathrm{CN}^{-}$. Then cells were washed with PBS five times. Fluorescence images were monitored at 425-520 nm for blue channels and the white light channel.

Next, HeLa cells (Figure 7) were incubated with different concentrations of probe 1 for $1 \mathrm{~h}$ : A, E with PBS; B, F with $2.5 \mu \mathrm{M}$ probe 1 ); C, G with $5 \mu \mathrm{M}$ probe 1 ; D, H with $10 \mu \mathrm{M}$ probe 1 . Then cells were washed with PBS five times. Then all cells were incubated with $80 \mu \mathrm{M} \mathrm{CN}^{-}$for $15 \mathrm{~min}$. Cell imaging was carried out after washing cells with PBS five times.

\section{Conclusions}

In summary, a colorimetric fluorescent probe $\mathbf{1}$ bearing triphenylamine-thiophene and dicyanovinyl groups has been synthesized. Probe 1 exhibited prominent selectivity and sensitivity for detecting cyanide anion with a significant turn-on fluorescent response in PBS/DMSO $(4 / 6, v / v$, $\mathrm{pH}=7.4)$ solution. Moreover, a low detection limit $(\mathrm{LOD}, 51 \mathrm{nM})$ was achieved and it was noted that the probe 1 has potential for detecting level of cyanide anion in drinking water according to the requirements of the WHO $(1.9 \mu \mathrm{M})$. In addition, good cell membrane permeability and low cytotoxicity to HeLa cells were also observed, suggesting its promising potential in bio-imaging.

Supplementary Materials: The following are available online at www.mdpi.com/1424-8220/17/2/405/s1: Additional spectral data for probe 1 and spectroscopic characterization of compounds 1-3.

Acknowledgments: This work was supported by the Basic Research Project of Sichuan Province (2014JY0205). We thank the Analytical and Testing Center of Sichuan University for fluorescent measurements.

Author Contributions: Li Yang and Qing-Fei Huang conceived and designed the experiments; Zi-Hua Zheng performed the synthetic and fluorescent experiments; Zhi-Ke Li and Lin-Jiang Song performed cell imaging; Qi-Wei Wang contributed reagents; Li Yang wrote the paper.

Conflicts of Interest: The authors declare no conflict of interest.

\section{References}

1. Busschaert, N.; Caltagirone, C.; Rossom, W.V.; Gale, P.A. Applications of supramolecular anion recognition. Chem. Rev. 2015, 115, 8038-8155. [CrossRef] [PubMed]

2. Wang, F.; Wang, L.; Chen, X.; Yoon, J. Recent progress in the development of fluorometric and colorimetric chemosensors for detection of cyanide ions. Chem. Soc. Rev. 2014, 43, 4312-4324. [CrossRef] [PubMed]

3. Merwe, S.W.; Schoeller, F.; Bolzer, W.; Germonper, R.; Heller, L.; Filho, E.H.; Formaggia, D.M.E.; Blum, J.C.; Omori, M.J.; Mancuso, P.C.S. Guidelines for Drinking-Water Quality; World Health Organization: Geneva, Switzerland, 1996. 
4. Kulig, K.W. Cyanide Toxicity; U.S. Department of Health and Human Services: Atlanta, GA, USA, 1991.

5. Anzenbacher, P.J.; Tyson, D.S.; Jursikova, K.; Castellano, F.N. Luminescence lifetime-based sensor for cyanide and related anions. J. Am. Chem. Soc. 2002, 124, 6232-6233. [CrossRef] [PubMed]

6. Ishii, A.; Seno, H.; Watanabe-Suzuki, K.; Suzuki, O. Determination of cyanide in whole blood by capillary gas chromatography with cryogenic oven trapping. Anal. Chem. 1998, 70, 4873-4876. [CrossRef] [PubMed]

7. Timofeyenko, Y.G.; Rosentreter, J.J.; Mayo, S. Piezoelectric quartz crystal microbalance sensor for trace aqueous cyanide ion determination. Anal. Chem. 2007, 79, 251-255. [CrossRef] [PubMed]

8. Ding, G.; Zhou, H.; Xu, J.; Lu, X. Electrofluorochromic detection of cyanide anions using a benzothiadiazolecontaining conjugated copolymer. Chem. Commun. 2014, 50, 655-657. [CrossRef] [PubMed]

9. Suzuki, T.; Hiolki, A.; Kurahashi, M. Development of a method for estimating an accurate equivalence point in nickel titration of cyanide ions. Anal. Chim. Acta 2003, 476, 159-165. [CrossRef]

10. Cacace, D.; Ashbaugh, H.; Kouri, N.; Bledsoe, S.; Lancaster, S.; Chalk, S. Spectrophotometric determination of aqueous cyanide using a revised phenolphthalin method. Anal. Chim. Acta 2007, 589, 137-141. [CrossRef] [PubMed]

11. Maldonado, C.R.; Touceda-Varela, A.; Jonesa, A.C.; Mareque-Rivas, J.C. A turn-on fluorescence sensor for cyanide from mechanochemical reactions between quantum dots and copper complexes. Chem. Commun. 2011, 47, 11700-11702. [CrossRef] [PubMed]

12. Lee, K.S.; Kim, H.J.; Shin, I.; Hong, J.I. Fluorescent chemodosimeter for selective detection of cyanide in water. Org. Lett. 2008, 10, 49-51. [CrossRef] [PubMed]

13. Badugu, R.; Lakowicz, J.R.; Geddes, C.D. Fluorescence intensity and lifetime-based cyanide sensitive probes for physiological safeguard. Anal. Chim. Acta 2004, 522, 9-17. [CrossRef]

14. Badugu, R.; Lakowicz, J.R.; Geddes, C.D. Enhanced fluorescence cyanide detection at physiologically lethal levels: Reduced ICT-based signal transduction. J. Am. Chem. Soc. 2005, 127, 3635-3641. [CrossRef] [PubMed]

15. Jung, H.S.; Han, J.H.; Kim, Z.H.; Kang, C.; Kim, J.S. Coumarin-Cu(II) ensemble-based cyanide sensing chemodosimeter. Org. Lett. 2011, 13, 5056-5059. [CrossRef] [PubMed]

16. Lee, H.; Kim, H.J. Highly selective sensing of cyanide by a benzochromene-based ratiometric fluorescence probe. Tetrahedron Lett. 2012, 53, 5455-5457. [CrossRef]

17. Park, S.; Kim, H.J. Highly activated Michael acceptor by an intramolecular hydrogen bond as a fluorescence turn-on probe for cyanide. Chem. Commun. 2010, 46, 9197-9199. [CrossRef] [PubMed]

18. Xu, Z.; Chen, X.; Kim, H.N.; Yoon, J. Sensors for the optical detection of cyanide ion. Chem. Soc. Rev. 2010, 39, 127-137. [CrossRef] [PubMed]

19. Kang, N.Y.; Ha, H.H.; Yun, S.W.; Yu, Y.H.; Chang, Y.T. Diversity-driven chemical probe development for biomolecules: Beyond hypothesis-driven approach. Chem. Soc. Rev. 2011, 40, 3613-3626. [CrossRef] [PubMed]

20. Zou, Q.; Zou, L.; Tian, H. Detection and adsorption of $\mathrm{Hg}^{2+}$ by new mesoporous silica and membrane material grafted with a chemodosimeter. J. Mater. Chem. 2011, 21, 14441-14447. [CrossRef]

21. Zou, Q.; Tian, H. Chemodosimeters for mercury(II) and methylmercury(I) based on 2,1,3-benzothiadiazole. Sens. Actuators B 2010, 149, 20-27. [CrossRef]

22. Ren, J.Q.; Zhu, W.H.; Tian, H. A highly sensitive and selective chemosensor for cyanide. Talanta 2008, 75, 760-764. [CrossRef] [PubMed]

23. Gong, W.T.; Zhang, Q.L.; Shang, L.; Gao, B.; Ning, G.L. A new principle for selective sensing cyanide anions based on 2-hydroxy-naphthaldeazine compound. Sens. Actuators B 2013, 177, 322-326. [CrossRef]

24. Jo, J.; Lee, D. Turn-on fluorescence detection of cyanide in water: Activation of latent fluorophores through remote hydrogen bonds that mimic peptide $\beta$-turn motif. J. Am. Chem. Soc. 2009, 131, 16283-16291. [CrossRef] [PubMed]

25. Gimeno, N.; Li, X.; Durrant, J.R.; Vilar, R. Cyanide sensing with organic dyes: Studies in solution and on nanostructured $\mathrm{Al}_{2} \mathrm{O}_{3}$ surfaces. Chem. Eur. J. 2008, 14, 3006-3012. [CrossRef] [PubMed]

26. Chen, X.; Nam, S.; Kim, G.; Song, N.; Jeong, Y.; Shin, I.; Kim, S.K.; Kim, J.; Park, S.; Yoon, J. Cyanide sensing with organic dyes: Studies in solution and on nanostructured $\mathrm{Al}_{2} \mathrm{O}_{3}$ surfaces. Chem. Commun. 2010, 46, 8953-8955. [CrossRef] [PubMed]

27. Dai, Z.; Boon, E.M. Engineering of the heme pocket of an H-NOX domain for direct cyanide detection and quantification. J. Am. Chem. Soc. 2010, 132, 11496-11503. [CrossRef] [PubMed] 
28. Lee, J.H.; Jeong, A.R.; Shin, I.S.; Kim, H.J.; Hong, J.I. Fluorescence turn-on sensor for cyanide based on a cobalt(II)-coumarinylsalen complex. Org. Lett. 2010, 12, 764-767. [CrossRef] [PubMed]

29. Liu, Y.L.; Lv, X.; Zhao, Y.; Liu, J.; Sun, Y.Q.; Wang, P.; Guo, W. A Cu(II)-based chemosensing ensemble bearing rhodamine B fluorophore for fluorescence turn-on detection of cyanide. J. Mater. Chem. 2012, 22, 1747-1750. [CrossRef]

30. Ajayakumar, M.R.; Mukhopadhyay, P. Single-electron transfer driven cyanide sensing: A new multimodal approach. Org. Lett. 2010, 12, 2646-2649. [CrossRef] [PubMed]

31. Ajayakumar, M.R.; Asthana, D.; Mukhopadhyay, P. Core-modified naphthalenediimides generate persistent radical anion and cation: New panchromatic NIR probes. Org. Lett. 2012, 14, 4822-4825. [CrossRef] [PubMed]

32. Ajayakumar, M.R.; Mandal, K.; Rawat, K.; Asthana, D.; Pandey, R.; Sharma, A.; Yadav, S.; Ghosh, S.; Mukhopadhyay, P. Single electron transfer-driven multi-dimensional signal read-out function of TCNQ as an "Off-the-Shelf" detector for cyanide. ACS Appl. Mater. Interfaces 2013, 5, 6996-7000. [CrossRef] [PubMed]

33. Huo, F.J.; Su, J.; Sun, Y.Q.; Yin, C.X.; Chao, J.B. A new ring-opening chromene molecule: Colorimetric detection of cyanide anion. Chem. Lett. 2010, 39, 738-740. [CrossRef]

34. Peng, M.J.; Guo, Y.; Yang, X.F.; Wang, L.Y.; An, J. A highly selective ratiometric and colorimetric chemosensor for cyanide detection. Dyes Pigment. 2013, 98, 327-332. [CrossRef]

35. Shan, Y.; Liu, Z.; Cao, D.; Sun, Y.; Wang, K.; Chen, H. Nitro substituted chalcone derivatives as quick-response chemosensors for cyanide anions. Sens. Actuators B Chem. 2014, 198, 15-19. [CrossRef]

36. Sun, X.; Wang, Y.; Deng, X.; Zhang, J.; Zhang, Z. A colorimetric and ratiometric fluorescent probe for the selective detection of cyanide anions in aqueous media and living cells. RSC. Adv. 2016, 6, 10266-10271. [CrossRef]

37. Lv, X.; Liu, J.; Liu, Y.L.; Zhao, Y.; Chen, M.L.; Wang, P.; Guo, W. Rhodafluor-based chromo-and fluorogenic probe for cyanide anion. Sens. Actuators B Chem. 2011, 158, 405-410. [CrossRef]

38. Jeong, Y.H.; Lee, C.H.; Jang, W.D. A Diketopyrrolopyrrole-Based Colorimetric and Fluorescent Probe for Cyanide Detection. Chem. Asian J. 2012, 7, 1562-1566. [CrossRef] [PubMed]

39. Yuan, L.; Lin, W.Y.; Yang, Y.T.; Song, J.Z.; Wang, J.L. Rational design of a highly reactive ratiometric fluorescent probe for cyanide. Org. Lett. 2011, 13, 3730-3733. [CrossRef] [PubMed]

40. Kim, H.J.; Ko, K.C.; Lee, J.H.; Lee, J.Y.; Kim, J.S. KCN sensor: Unique chromogenic and "turn-on" fluorescent chemodosimeter: Rapid response and high selectivity. Chem. Commun. 2011, 47, 2886-2888. [CrossRef] [PubMed]

41. Li, Y.; Ren, T.; Dong, W.J. Tuning photophysical properties of triphenylamine and aromatic cyano conjugate-based wavelength-shifting compounds by manipulating intramolecular charge transfer strength. J. Photochem. Photobiol. A Chem. 2013, 251, 1-9. [CrossRef]

42. Cheng, X.; Zhou, Y.; Qin, J.; Li, Z. Reaction-based colorimetric cyanide chemosensors: Rapid naked-eye detection and high selectivity. ACS Appl. Mater. Interfaces 2012, 4, 2133-2138. [CrossRef] [PubMed]

43. Lee, C.H.; Yoon, H.J.; Shim, J.S.; Jang, W.D. A Boradiazaindacene-based turn-on fluorescent probe for cyanide detection in aqueous media. Chem. Eur. J. 2012, 18, 4513-4516. [CrossRef] [PubMed]

44. Yang, L.; Li, X.; Yang, J.; Qu, Y.; Hua, J. Colorimetric and ratiometric near-infrared fluorescent cyanide chemodosimeter based on phenazine derivatives. ACS Appl. Mater. Interfaces 2013, 5, 1317-1326. [CrossRef] [PubMed]

45. Zhang, Q.; Zhang, J.; Zuo, H.; Wang, C.; Shen, Y. A novel colorimetric and fluorescent sensor for cyanide anions detection based on triphenylamine and benzothiadiazole. Tetrahedron 2016, 72, 1244-1248. [CrossRef]

46. Qu, Y.; Jin, B.; Liu, Y.; Wu, Y.; Yang, L.; Wu, J.; Hua, J. A new triphenylamine fluorescent dye for sensing of cyanide anion in living cell. Tetrahedron Lett. 2013, 54, 4942-4944. [CrossRef]

47. Zou, Q.; Li, X.; Xu, Q.; Ågren, H.; Zhao, W.; Qu, Y. A near-infrared "on-off" fluorescent and colourimetric cyanide chemodosimeter based on phenothiazine with applications in living cell imaging. RSC Adv. 2014, 4, 59809-59816. [CrossRef]

48. Wang, S.; Xu, H.; Yang, Q.; Song, Y.; Li, Y. A triphenylamine-based colorimetric and "turn-on" fluorescent probe for detection of cyanide anions in live cells. RSC Adv. 2015, 5, 47990-47996. [CrossRef]

49. Yang, Y.; Yin, C.; Huo, F.; Chao, J.; Zhang, Y.; Cheng, F. A new highly selective and turn-on fluorescence probe for detection of cyanide. Sens. Actuators B Chem. 2014, 193, 220-224. [CrossRef] 
50. Sun, Y.; Fan, S.; Duan, L.; Li, R. A ratiometric fluorescent probe based on benzo [e] indolium for cyanide ion in water. Sens. Actuators B Chem. 2013, 185, 638-643. [CrossRef]

51. Pati, P.B.; Zade, S.S. Dicyanovinyl terthiophene as a reaction based colorimetric and ratiometric fluorescence probe for cyanide anions. RSC Adv. 2013, 3, 13457-13462. [CrossRef] 